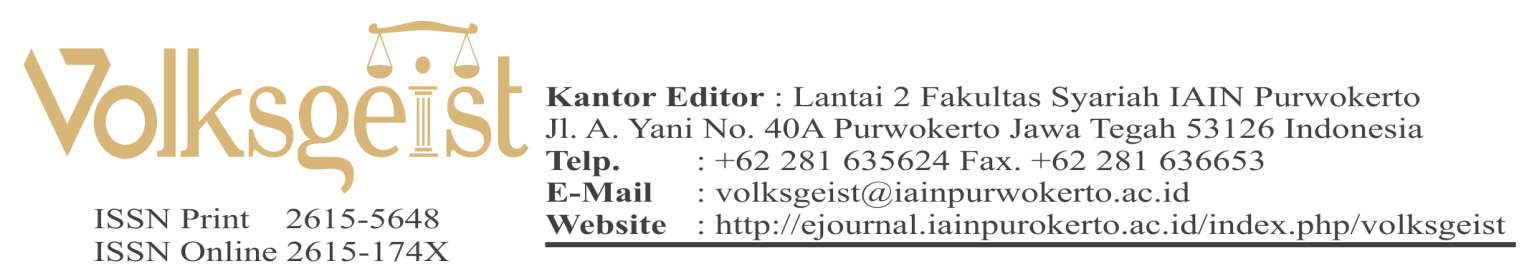

\title{
Analisis terhadap Dualitas Peraturan Menteri dalam Sistem Peraturan Perundang-Undangan di Indonesia
}

\author{
Irfan Ardyan Nusanto \\ Fakultas Hukum Universitas Gadjah Mada Yogyakarta \\ Email: momokoponx@mail.ugm.ac.id
}

\begin{abstract}
Abstark
Artikel ini mengkaji mengenai dualitas peraturan menteri dalam sistem peraturan perundangundangan di Indonesia berdasarkan sumber kewenangan pembentukannya dalam UU No. 12 Tahun 2011 tentang Pembentukan Peraturan Perundang-undangan (UU P3). Pendekatan yang digunakan dalam penelitian ini adalah pendekatan konseptual (conceptual approach) dan pendekatan undangundang (statute approach). Artikel ini menyimpulkan bahwa dua jenis peraturan menteri yang diakui sebagai peraturan perundang-undangan oleh UU P3 harus dibedakan. Peraturan menteri yang lahir karena perintah peraturan perundang-undangan yang lebih tinggi (delegated legislation) dapat dikategorikan sebagai peraturan pelaksanaan (verordnung). Sedangkan peraturan menteri yang dibentuk berdasarkan kewenangan yang melekat pada jabatannya sebagai menteri (inherent aan het bestuur) dapat dikategorikan sebagai beleidsregel yang kedudukanya sebagai peraturan kebijaksanaan. Meskipun keduannya sama-sama diakui sebagai peraturan perundang-undangan, tetapi keduannya memiliki desain, latar belakang dan karakter yang berbeda sehingga implikasinya substansi, daya ikat, kedudukan hierarki dan mekanisme pengujiannya pun berbeda pula. Oleh sebab itu, peraturan menteri yang berupa beleidsregel tidak dapat diterapkan seperti peraturan menteri yang berupa peraturan pelaksanaan (verordnung) pada umumnya.
\end{abstract}

Kata Kunci: peraturan menteri, peraturan kebijakan, peraturan pelaksanaan.

\section{Abstract}

This article examines the duality of ministerial regulations in Indonesian regulation system based on their making authority sources according to Law No. 12 Year 2011 concerning Regulation Making Rules (UU P3). The approach methods used in this research are conceptual approach and statute approach. This article concludes there are two ministerial regulations which recognized as regulations by UU P3 that should be distinguished. Ministerial regulation which was made by higher regulations order (delegated legislation) could be categorized as an implementing rule (verordnung). Whereas, ministerial regulation which was made based on ministery position authority (inherent aat het bestuur) could be categorized as a beleidsregel, standing as policy rules. Though, the two of them were recognized as regulations, however, they have different design, background and character, thus, their substance, binding power, hierarchy position and review mechanism, were not the same. Therefore, ministerial regulation which was beleidsregel could not be applied as the same as implementing regulation (verordnung).

Keywords: ministry regulation, policy rule, implementing rule. 


\section{Sejarah Artikel}

Dikirim: 14 November 2020

Direview: 07 Juni 2021

Diterima: 19 Juni 2021

Diterbitkan: 23 Juni 2021

\section{PENDAHULUAN}

Dalam konteks sistem presidensial, Presiden selaku pemegang fungsi eksekutif berkuasa penuh dan memiliki peranan besar dalam menjalankan fungsi pemerintahan karena ia merupakan eksekutif tunggal ${ }^{1}$, terutama dalam mewujudkan tujuan welfare state. Kranenburg mengatakan bahwa negara harus bertindak aktif dalam mengupayakan kesejahteraan dan bertindak adil terhadap seluruh rakyat. ${ }^{2}$ Dalam menjalankan fungsinya, Presiden dibantu oleh para menteri-menteri negara ${ }^{3}$ yang merupakan perangkat pemerintah yang membidangi urusan tertentu dalam pemerintahan. ${ }^{4}$ Oleh sebab itu, menteri juga memiliki kewenangan untuk bertindak sebagai agen eksekutif dalam melaksanakan urusan tertentu pemerintahan. Bersamaan hal tersebut, melahirkan kewenangan menteri untuk membentuk atau menetapkan suatu peraturan menteri (permen) guna melancarkan pelaksanaan penyelenggaraan pemerintahan. Peraturan menteri ini menjadi urgen, karena dalam konsep negara hukum, peraturan perundang-undangan menjadi landasan pemerintah untuk melakukan setiap tindakannya (wetmatigheid van bestuur).

\footnotetext{
1 Rina Martini et al., "Pemilihan Pejabat Negara Pada Lembaga Negara Penunjang Dalam Sistem Presidensial: Studi Kasus KPU RI Periode 2017-2022," Politika Jurnal Ilmu Politik 10, no. 1 (2019).

2 Wicipto Setiadi and Ali Imran Nasution, "Sanksi Administratif Terhadap Kepala Daerah Yang Tidak Melaksanakan Program Strategis Nasional," Jurnal Penelitian Hukum De Jure 20, no. 4 (2020).

3 Lihat Pasal 17 Undang Undang Dasar Negara Republik Indonesia 1945

4 Lihat Pasal 1 ayat (1) UU No. 39 Tahun 2008 Tentang Kementerian Negara
}

Secara normatif, UU No. 12 Tahun 2011 tentang Pembentukan Peraturan Perundangundangan jo UU No. 15 Tahun 2019 (UU P3) memaknai peraturan perundang-undangan sebagai peraturan tertulis yang memuat norma hukum yang mengikat secara umum dan dibentuk atau ditetapkan oleh lembaga negara atau pejabat yang berwenang melalui prosedur yang ditetapkan dalam peraturan perundang-undangan mengatur hierarki peraturan perundang-undangan di Indonesia. ${ }^{5}$ Pasal 7 ayat (1) menjelaskan mengenai hierarki peraturan perundang-undangan di Indonesia yang meliputi: UUD 1945; TAP MPR; UU/ Perppu; Peraturan Pemerintah; Peraturan Presiden; Peraturan Daerah Propinsi; Peraturan Daerah Kabupaten atau Kota. ${ }^{6}$

Meskipun peraturan menteri tidak termasuk dalam hierarki tersebut, tetapi keberadaannya disebutkan dalam Pasal 8 yang menyatakan ${ }^{7}$

“(1) Jenis peraturan perundang-undangan selain sebagaimana dimaksud dalam Pasal 7 ayat (1) mencakup peraturan ... Menteri, ... ;

(2) Peraturan perundang-undangan sebagaimana dimaksud pada ayat (1) diakui keberadaanya dan mempunyai kekuatan hukum mengikat sepanjang diperintahkan oleh peraturan perundang-undangan yang lebih tinggi atau dibentuk berdasakan kewenangan."

Sehingga, peraturan menteri diakui sebagai peraturan perundang-undangan apabila dibentuk berdasarkan perintah peraturan perundang-undangan yang lebih tinggi atau berdasarkan kewenangan karena jabatannya sebagai menteri itu sendiri. Maka, di sini nampak adanya dualitas peraturan menteri

$5 \quad$ Lihat Pasal 1 angka 2 UU No. 12 Tahun 2011 Tentang Pembentukan Peraturan Perundang-Undangan

$6 \quad$ Lihat Pasal 7 ayat (1) UU No. 12 Tahun 2011 tentang Pembentukan Peraturan Perundang-undangan.

7 Lihat Pasal 8 UU No. 12 Tahun 2011 Tentang Pembentukan Peraturan Perundang-Undangan 
didasarkan pada kewenangan pembentukannya yang berbeda. Implikasinya, peraturan menteri yang dibentuk berdasakan kewenangan dapat diterapkan sebagaimana peraturan menteri yang lahir karena perintah peraturan perundangundangan yang lebih tinggi karena dianggap sama (peraturan menteri).

Sebelumnya, Nindya Chairunnisa dalam tulisannya yang berjudul "Kewenangan Pembentukan Peraturan Menteri Sebagai Jenis Peraturan Perundang-undangan" mengatakan bahwa peraturan menteri merupakan peraturan pendelegasian, karena menteri tidak memiliki kewenangan atribusi untuk membuat peraturan perundang-undangan. Sehingga, menteri hanya dapat membuat peraturan menteri apabila terdapat pendelegasian kewenangan pembentukan peraturan perundang-undangan baik secara eksplisit maupun implisit. Maka, peraturan menteri yang tidak berdasarkan pendelegasian kewenangan tidak dapat diakui sebagai peraturan perundang-undangan dan tidak mempunyai kekuatan hukum mengikat berdasarkan ketentuan pada Pasal 8 ayat (2) UU No. 12 Tahun 2011. ${ }^{8}$

Tesano, mengkaji mengenai hierarkisitas peraturan menteri dalam sistem peraturan perundang-undangan yang disandingkan dengan peraturan daerah dengan judul "Hirarkhisitas Kedudukan Peraturan Menteri Dengan Peraturan Daerah Dalam Sistem Peraturan Perundang-undangan Ditinjau Dari Undang-undang No. 12 Tahun 2011" meyatakan bahwa kedudukan peraturan menteri mempunyai derajat yang lebih tinggi dari peraturan daerah, karena kedudukan lembaga kementerian sebagai pembantu Presiden yang menjalankan garis kebijakan umum dan ruang lingkup keberlakuannya secara nasional,

\footnotetext{
8 Nindya Chairunnisa Zahra, "Kewenangan Pembentukan Peraturan Menteri Sebagai Jenis Peraturan Perundang-Undangan" (Universitas Indonesia, 2014), http://lib.ui.ac.id/naskahringkas/2016-10//S58379Nindya Chairunnisa Zahrariyadi.
}

di mana muatan materi peraturan menteri merupakan penjabaran langsung dari undangundang, peraturan presiden dan peraturan pemerintah. Di samping itu, peraturan menteri juga memiliki levelitas yang lebih tinggi dibandingkan dengan peraturan daerah, sehingga menempatkan peraturan menteri dalam konsideran "mengingat" bukanlah suatu kesalahan normatif."

Hal menarik disampaikan oleh Sofyan Apendi dalam tulisannya yang berjudul "Ketiadaan Peraturan Menteri Dalam Hierarki Peraturan Perundang-undangan Nasional dan Implikasinya Terhadap Penataan Regulasi Dalam Sistem Hukum Nasional" yang menyatakan bahwa peraturan menteri sebaiknya tidak diakui lagi sebagai peraturan pelaksana tingkat pusat paling akhir dan ditiadakan dari sistem peraturan perundang-undangan nasional. Karena peraturan menteri malah menimbulkan over regulasi. Dengan karakteristik yang sama, namun dengan level yang lebih kuat, seharusnya peraturan pelaksana dapat berhenti pada tingkat perpres. Pada dasarnya terhadap peraturan menteri yang berupa peraturan delegasi, mudah untuk ditiadakan dengan cara tidak mendelegasikan pembuatan ketentuan lebih lanjut kepada peraturan menteri. Akan tetapi dengan adanya ketentuan Pasal 8 ayat (2) UU P3 justru menjadi kendala dalam peniadaan peraturan menteri, karena menimbulkan penafsiran bahwa menteri dapat membuat peraturan perundang-undangan tanpa adanya delegasi kewenangan. Di mana UU No. 39 Tahun 2008 yang mengatur keberadaan menteri sendiri tidak memberikan atribusi kewenangan pembentukan peraturan perundang-undangan kepada menteri, sehingga menteri seharusnya hanya dapat membuat peraturan sepanjang ada aturan yang mendelegasikan.$^{10}$

9 Tesano Tesano, "Hirarkhisitas Kedudukan Peraturan Menteri Dengan Peraturan Daerah Dalam Sistem Peraturan Perundang-Undangan Ditinjau Dari Undang-Undang No. 12 Tahun 2011”2, no. 2 (2015).

10 Sofyan Apendi, "Ketiadaan Peraturan Menteri

Dalam Hierarki Peraturan Perundang-Undangan 
Tulisan ini menganalisis terkait sumber kewenangan pembentukan peraturan menteri serta dualitas yang timbul karena perbedaan kewenangan pembentukannya, sehingga pokok pembahasan berfokus pada perbedaan diantara keduannya. Di mana menteri selaku eksekutif dapat membuat dua jenis regulasi yang diakui sebagai peraturan perundang-undangan meskipun berasal dari sumber kewenangan yang berbeda dan tetap diakui sebagai peraturan menteri dalam sistem peraturan perundangundangan. Penelitian ini bersifat normatif dengan pendekatan konseptual (conceptual approach) dan pendekatan undang-undang (statutory approach), sehingga pembahasan lebih fokus pada konsep dan pengaturan dalam peraturan perundang-undangan di Indonesia. Pembahasan dilakukan dengan menganalisis sumber kewenangan pembentukan antara kedua jenis peraturan menteri dan kemudian akan dilanjutkan dengan menganalisis perbedaan antara kedua regulasi tersebut secara komprehensif.

\section{PEMBAHASAN}

\section{Peraturan Menteri Berdasarkan Sumber Kewenangan Pembentukannya}

Presiden secara atributif memperoleh kewenangan untuk menetapkan peraturan pemerintah (PP) guna menjalankan undangundang sebagaimana mestinya. ${ }^{11}$ Menteri, yang merupakan pembantu Presiden yang memimpin suatu kementerian berada di bawah dan bertanggung jawab kepada Presiden, ${ }^{12}$ dapat diperintahkanolehPresidenuntukmelaksanakan pengaturan lebih lanjut baik melalui PP maupun

Nasional Dan Implikasinya Terhadap Penataan Regulasi Dalam Sistem Hukum Nasional," PALAR (Pakuan Law Review) 07, no. 01

11 Lihat Pasal 5 ayat (2) Undang Undang Dasar Negara Republik Indonesia 1945.

12 Lihat Pasal 1 ayat (2) dan Pasal 3 UU No. 39

Tahun 2008 tentang Kementerian Negara.
Perpres. Konstitusi juga menyebutkan secara jelas mengenai eksistensi menteri dalam Bab V Pasal 17 tentang Kementerian Negara, sehingga kelembagaan menteri dapat dikatakan memiliki constitutional importance. ${ }^{13}$ Bahkan, sebagai pembantu Presiden, menteri dapat mewakili Presiden dalam suatu pembahasan RUU bersama legislature. Agar dinilai lebih efektif, muncul saran bahwa seharusnya Pasal 20 ayat (2) UUD 1945 lebih tepat menggunakan istilah "pemerintahan", bukan "presiden". Karena menteri termasuk bagian dari pemerintahan. ${ }^{14}$

C.S.T Kansil menjelaskan mengenai kedudukan menteri, meskipun menteri diangkat dan diberhentikan oleh Presiden, menterilah yang terutama menjalankan kekuasaan pemerintahan (pouvonir executive). ${ }^{15}$ Jimly Asshiddiqie juga menjelaskan alasan mengapa menteri diatur tersendiri dalam $\mathrm{Bab} \mathrm{V}$ dan terpisah dari Bab III tentang kekuasaan pemerintahan ini menunjukan bahwa kedudukan menteri sangat penting dalam ketatanegaraan menurut UUD 1945. ${ }^{16}$ Meskipun kedudukannya sebagai pembantu Presiden, menteri menjalankan kekuasaan eksekutif sehari-hari. Ia juga mejelaskan bahwa menteri merupakan pimpinan pemerintahan dalam arti yang sebenarnya di bidang tugas masing-masing sehingga kepala eksekutif yang sebenarnya bukanlah Presiden, melainkan menteri yang bertanggung jawab kepada Presiden. Dalam penjelasan UUD 1945 sebelum amandemen menjelaskan bahwa menteri bukanlah pejabat

13 Jimly Asshiddiqie, Perkembangan Dan Konsolidasi Lembaga Negara Pasca Reformasi (Jakarta: Sekretariat Jenderal dan Kepaniteraan Mahkamah Konstitusi RI, 2006).

14 Rahayu Prasetyaningsih, "Menakar Kekuasaan Presiden Dalam Pembentukan Peraturan PerundangUndangan Menurut Undang-Undang Dasar 1945," Padjadjaran Jurnal Ilmu Hukum 4, no. 2 (2017).

15 C.S.T. Kansil, Sistem Pemerintahan Indonesia (Jakarta: Bumi Aksara, 2005).

16 Asshiddiqie, Perkembangan Dan Konsolidasi Lembaga Negara Pasca Reformasi. 
yang biasa. ${ }^{17}$ Maka, dari sini terlihat kedudukan menteri dalam ketatanegaraan di Indonesia memiliki fungsi utama sebagai pelaksana tugas eksekutif Presiden sehari-hari, termasuk dalam menjalankan perintah undang-undang.

Di sinilah peran para menteri sebagai pembantuPresidenuntukmengimplementasikan perintah peraturan perundang-undangan yang lebih tinggi ke tataran yang lebih konkrit. Adanya perintah ini secara tidak langsung memberikan kewenangan pada menteri untuk membentuk suatu peraturan yang bersifat teknis dalam bentuk peraturan menteri (permen). Maka, terjadi pelimpahan kewenangan membentuk peraturan (delegated legislation). MP Jain, dalam Sukardi dan E. Prajwalita Widiati, menjelaskan, "delegated legislation used to denote: 1) the subsidiary legislation itself made by the administration in pursuance of the power delegated to it by legislature, and 2) the exercise of the power by the agency". ${ }^{18}$ Maka, menteri dapat membuat peraturan yang bersifat mengikat karena adanya perintah peraturan perundang-undangan yang lebih tinggi.

Secara teori, hanya fungsi legislatif yang memiliki wewenang untuk membentuk suatu peraturan perundang-undangan (supreme legislation) yang mengikat secara umum. Akan tetapi, dikarenakan pembentuk undang-undang tidak mungkin untuk mengatur norma secara rinci dan detail untuk diimplementasikan, maka kewenangan untuk mengatur hal-hal yang bersifat teknis dilimpahkan kepada eksekutif. Hal ini juga dijelaskan dalam UU P3 bahwa peraturan perundang-undangan yang lebih tinggi dapat mendelegasikan kewenangan mengatur lebih lanjut kepada peraturan perundang-undangan yang lebih rendah. ${ }^{19}$

\section{Asshiddiqie.}

18 Sukardi Sukardi and E. Prajwalita Widiati, "Pendelegasian Pengaturan Oleh Undang-Undang Kepada Peraturan Yang Lebih Rendah Dan Akibat Hukumnya," Yuridika 27, no. 2 (2012).

19 Lihat Lampiran UU No. 12 Tahun 2011 tentang Pembentukan Peraturan Perundang-undangan.
Jain menerangkan bahwa tidak mungkin untuk membentuk suatu undang-undang secara komplit dan detail karena tiga hal, yaitu: lembaga legislatif pekerjaannya sudah terlalu banyak; undang-undang yang terlalu detail justru akan membingungkan rakyat pembacanya; dan kemajuan sosial-ekonomi begitu pesat sehingga hanya kelompok expert saja yang mampu memahami permasalahan secara detail. ${ }^{20}$ Sehingga pengaturan lebih lanjut diturunkan kepada peraturan perundangundangan yang lebih rendah.

Menteri dapat membentuk suatu peraturan menteri sebagai peraturan perundang-undangan didasarkan pada dua kewenangan, yaitu berdasarkan Pasal 8 ayat (2) yang menyebutkan “... mempunyai kekuatan hukum mengikat sepanjang diperintahkan oleh peraturan perundang-undangan yang lebih tinggi atau dibentuk berdasarkan kewenangan". ${ }^{21}$ Sehingga, peraturan menteri dipandang mempunyai kekuatan hukum mengikat secara umum sepanjang diperintah oleh peraturan perundang-undangan yang lebih tinggi (delegated legislation) dan karena didasarkan pada kewenangan yang melekat pada jabatan menteri (inherent aan het bestuur).

Untuk melihat sumber kewenangan pembentukan peraturan menteri, perlu dilihat dari sumber perintah pembentukannya. Pertama, peraturan menteri yang lahir karena perintah peraturan perundang-undangan yang lebih tinggi, dapat dilihat dan dilacak melalui konsiderannya. Misalnya, Peraturan Menteri Lingkungan Hidup dan Kehutanan No. P.12/ MENLHK/SETJEN/PLB.3/5/2020 tentang Penyimpanan Limbah Bahan Berbahaya dan Beracun (B3). Dalam konsideran menimbang menyebutkan, "bahwa untuk melaksanakan

20 Sukardi and Widiati, "Pendelegasian Pengaturan Oleh Undang-Undang Kepada Peraturan Yang Lebih Rendah Dan Akibat Hukumnya."

21 Lihat Pasal 8 ayat (2) UU No. 12 Tahun 2011 tentang Pembentukan Peraturan Perundang-undangan. 
ketentuan Pasal 18 dan Pasal 19 ayat (5) Peraturan Pemerintah No. 101 Tahun 2014 tentang Pengelolaan Limbah Bahan Berbahaya dan Beracun (B3) perlu menetapkan peraturan menteri ...", dan pada bagian mengingat disebutkan landasan hukumnya, yaitu: Pasal 17 ayat (3) UUD 1945; UU No. 39 Tahun 2008 tentang Kementerian Negara; Peraturan Pemerintah No. 101 Tahun 2014 tentang Pengelolaan Limbah Bahan Berbahaya dan Beracun; Peraturan Presiden No. 16 Tahun 2015 tentang Kementerian Lingkungan Hidup dan Kehutanan; dan Peraturan Menteri Lingkungan Hidup dan Kehutanan No. P.18/ MENLHK-II/2015 tentang Organisasi dan Tata Kerja Kementerian Lingkungan Hidup dan Kehutanan. ${ }^{22}$

Adanya perintah untuk diatur lebih lanjut kepada peraturan menteri a quo dapat dijumpai pada Pasal 18 PP No. 101 Tahun 2014 tentang Pengelolaan Limbah Bahan Berbahaya dan Beracun yang menjelaskan, "Ketentuan lebih lanjut mengenai persyaratan tempat Penimpanan Limbah B3 sebagaimana dimaksud dalam Pasal 13 sampai dengan Pasal 17 diatur dalam Peraturan Menteri" dan Pasal 19 ayat (5), "Ketentuan lebih lanjut mengenai tata cara pengemasan Limbah B3, Pelabelan Limbah, dan pemberian Simbol Limbah B3 diatur dalam Peraturan Menteri". ${ }^{23}$ Di mana sebelumnya, PP tersebut juga memperoleh kewenangan pengaturan lebih lanjut melalui perintah dari UU No. 32 Tahun 2009 tentang Perlindungan dan Pengelolaan Lingkungan Hidup (UU PLH) yang disebutkan dalam Pasal 59 ayat (7), "Ketentuan lebih lanjut mengenai pengelolaan limbah B3 diatur dalam Peraturan Pemerintah" dan Pasal 61 ayat (3), "Ketentuan

22 Lihat konsideran Peraturan Menteri Lingkungan Hidup Dan Kehutanan No. P.12/MENLHK/SETJEN/ PLB.3/5/2020 Tentang Penyimpanan Limbah Bahan Berbahaya Dan Beracun (B3).

23 Lihat Pasal 18 dan Pasal 19 ayat (5) Peraturan Pemerintah No. 101 Tahun 2014 Tentang Pengelolaan Limbah Bahan Berbahaya Dan Beracun (B3). lebih lanjut mengenai tata cara dan persyaratan dumping limbah atau bahan diatur dalam Peraturan Pemerintah". 24

Berdasarkan hal tesebut, menunjukkan secara hierarkis telah terjadi pelimpahan kewenangan pembentukan peraturan perundangundangan (delegated legislation) secara sistematis dari UU ke PP, yang kemudian diturunkan ke peraturan menteri. Sehingga, lahirnya peraturan menteri a quo merupakan perintah dari peraturan perundang-undangan yang lebih tinggi untuk diatur oleh peraturan perundangundangan yang lebih rendah secara inline.

Kedua, untuk peraturan menteri yang dibentuk berdasarkan kewenangan, justru tidak didasarkan karena adanya perintah dari UU yang diturunkan, tetapi didasarkan karena jabatanya sebagai menteri yang juga menjalankan fungsi eksekutif. Seperti dalam Peraturan Menteri Koordinator Bidang Perekonomian No. 2 Tahun 2016 tentang Quick Wins Kementerian Koordinator Bidang Perekonomian Tahun 2016. Dalam konsideran bagian menimbang tidak dicantumkan pasal yang mendelegasikan kewenangan pembentukan peraturan perundang-undangan, melainkan hanya terdapat pertimbangan yang memuat frasa “... perlu menetapkan peraturan menteri ...”. ${ }^{25}$ Di sini dapat diartikan bahwa menteri karena jabatannya, merasa perlu untuk membentuk peraturan (inherent aan het bestuur). Meskipun dalam konsideran bagian mengingat terdapat beberapa regulasi yang dijadikan landasan hukum, akan tetapi regulasi tersebut hanya menjadi dasar yuridis yang menguatkan posisinya sebagai menteri yang menjalankan fungsi eksekutif. ${ }^{26}$ Peraturan

24 Lihat Pasal 59 ayat (7) dan Pasal 61 ayat (3) UU No. 32 Tahun 2009 Tentang Pengelolaan Lingkungan Hidup

25 Lihat konsideran Peraturan Menteri Koordinator Bidang Perekonomian No. 2 Tahun 2016 Tentang Quick Wins Kementerian Koordinator Bidang Perekonomian

26 Lihat konsideran Peraturan Menteri Koordinator Bidang Perekonomian No. 2 Tahun 2016 Tentang Quick 
menteri a quo sebenarnya hanya didasarkan pada adanya arahan reformasi birokrasi sebagaimana diamanatkan dalam Perpres No. 81 Tahun 2010 tentang Grand Design Reformasi Birokrasi. Dalam perpres tersebut tidak terjadi pendelegasian kewenangan maupun perintah untuk membentuk suatu peraturan perundangundangan, akan tetapi hanya menyebutkan bahwa Grand Design Reformasi Birokrasi 2010-2025 dalam perpres a quo sebagai acuan bagi kementerian/ lembaga/ pemerintah daerah dalam melakukan reformasi birokrasi dalam rangka mewujudkan tata kelola pemerintahan yang baik. ${ }^{27}$

Grand Design Reformasi Birokrasi sendiri merupakan rancangan induk yang berisi arah kebijakan pelaksanaan reformasi birokrasi nasional untuk kurun waktu 2010-2025. ${ }^{28}$ Setiap instansi baik kementerian, lembaga ataupun pemerintah daerah yang menjalankan fungsi pemerintahan memiliki kewenangan untuk menentukan kebijakan (freies ermessen) yang akan diambil dalam rangka pelaksanaan reformasi birokrasi dengan mengacu pada Grand Design tersebut. Di mana salah satu kebijakan yang dapat diambil ialah melalui penerapan program quick wins. Quick wins sendiri diartikan sebagai langkah inisiatif yang mudah dan cepat dicapai yang mengawali suatu program besar dan sulit. ${ }^{29}$ Di sini, setiap instansi memiliki kewenangan untuk menentukan quick wins apa yang akan diterapkan, sehingga setiap instansi berbeda-beda. Oleh sebab itu, dasar pembentukan peraturan menteri a quo terkait quick wins ialah semata-mata karena jabatannya

Wins Kementerian Koordinator Bidang Perekonomian

27 Lihat Pasal 2 Peraturan Presiden No. 81 Tahun 2010 Tentang Grand Design Reformasi Birokrasi 20102025

28 Lihat lampiran Peraturan Presiden No. 81 Tahun 2010 tentang Grand Design Reformasi Birokrasi 2010-2025.

29 Lihat lampiran Peraturan Presiden No. 81 Tahun 2010 tentang Grand Design Reformasi Birokrasi 2010-2025 (inherent aan het bestuur) sebagai Menteri Koordinator Bidang Perekonomian yang merupakan bagian dari rumpun eksekutif di bawah Presiden, sehingga dapat membuat dan menentukan kebijakan yang akan diterapkan pada instansinya untuk mengoptimalkan fungsinya melalui peraturan menteri dalam rangka reformasi birokrasi.

\section{Dualitas Peraturan Menteri dalam Sistem Peraturan Perundang-undangan di Indonesia}

Adannya dua sumber kewenangan pembentukan peraturan menteri jutrsu malah menciptakan dualitas peraturan menteri dalam sistem peraturan perundang-undangan di Indonesia. Di mana kedua regulasi tersebut sama-sama diakui sebagai bentuk peraturan perundang-undangan yang mengikat secara umum. Hal ini menimbulkan kerancuan baik secara teroritik maupun secara praktik jika kedua regulais tersebut diterapkan secara sama. Padahal, kenyataannya keduanya benar-benar berbeda jika dilihat dari beberapa hal, antara lain:

Pertama, dari jenis produk hukumnya. Peraturan yang dibentuk atas perintah peraturan perundang-undangan yang lebih tinggi dapat dikategorikan sebagai peraturan pelaksanaan (verordnung),, ${ }^{30}$ sedangkan peraturan menteri yang lahir berdasarkan kewenangan dapat dikategorikan sebagai peraturan kebijakan (beleidsregel). Kedua jenis peraturan ini merupakan dua hal yang berbeda. Frasa "berdasarkan kewenangan" dijelaskan sebagai penyelenggaraan urusan tertentu pemerintahan sesuai dengan ketentuan peraturan perundang-

30 Penulis menggunakan istilah verordnung untuk menyebut peraturan pelaksanaan sebagaimana digunakan oleh Hans Nawiasky untuk mengklasifikasikan "aturan pelaksana" yang dikutip oleh Noor M. Aziz, "Pengkajian Hukum Tentang Eksistensi Peraturan PerundangUndangan Di Luar Hierarki Berdasarkan UU No. 10 Tahun 2004 Tentang Pembentukan Peraturan PerundangUndangan," 2010. 
undangan. $^{31}$ Maka, secara sederhana, ketentuan tersebut medasarkan kewenangan pembentukan peraturan menteri tersebut pada adanya kewenangan menteri untuk melakukan suatu tindakan dalam rangka penyelenggaraan pemerintahan guna mencapai suatu tujuan tertentu. Akan tetapi ketentuan tersebut tidak menjelaskan bagaimana tindakan tersebut harus dilakukan (teknis). Di sini, menteri memiliki "kewenangan" untuk melakukan tindakan, "kewenangan" tersebut berasal dari jabatan karena ia sebagai menteri (inherent aan het bestuur). Atas dasar kewenangan tersebut, menteri dapat melakukan tindakan (termasuk membuat peraturan) tanpa harus terikat regulasi strict yang mengatur bagaimana tindakan tersebut harus dilakukan. Kewenangan ini dalam hukum administrasi dikenal dengan istilah freies ermessen (kewenangan bertindak bebas). Ridwan HR menjelaskan bahwa kewenangan ini merupakan konsekuensi logis dari konsepsi welfare state. Di mana konsep ini muncul untuk mengisi kekurangan dan kelemahan dari penerapan asas legalitas (wetmatigheid van bestuur). Ini berkaitan dengan fungsi pemerintahan untuk menyelenggarakan kesejahteraan umum. Karena dalam negara welfare state, dalam memenuhi kesejahteraan dan kepentingan masyarakat, asas legalitas saja dianggap tidak cukup. Di mana salah satu ciri keterbatasan hukum tertulis ditandai dengan adanya norma yang samar (vage norm) maupun ketentuan norma yang terbuka (open texture). ${ }^{32}$ Sehingga pemerintah diberi kewenangan untuk melakukan tindakan bebas yang tidak terikat dengan peraturan perundang-undangan (freies ermessen) atau lazimnya disebut dengan

31 Lihat Penjelasan Pasal 8 ayat (2) UU No. 12 Tahun 2011 tentang Pembentukan Peraturan Perundangundangan.

32 Nicken Sarwo Rini, "Penyalahgunaan Kewenangan Administrasi Dalam Undang-Undang Tindak Pidana Korupsi," Jurnal Penelitian Hukum De Jure 18, no. 2 (2018). diskresi (diskresionare power). ${ }^{33} \mathrm{Hal}$ ini selaras dengan pandangan SF Marbun yang juga menjelaskan bahwa agar servis publik mencapai hasil maksimal, maka administrasi negara diberi kemerdekaan tertentu untuk bertindak atas inisiatif sendiri dalam menghadapi suatu permasalahan yang membutuhkan penanganan cepat. $^{34}$

Kenneth Culp Davis menjelaskan, " $a$ public officer has discretion whenever the effective limits on his power leave him free to make a choice among possible courses of action or inaction". ${ }^{35}$ Maka, diskresi di sini diartikan sebagai opsional. Sehingga pilihan disini lebih diarahkan pada keputusan/tindakan pemerintah yang mengutamakan pencapaian tujuan atau sasaran (doelmatigheid), daripada kesesuaian dengan hukum (rechtmatigheid). ${ }^{36}$

UUNo. 30 Tahun 2014 tentang Adminsitrasi Pemerintahan (UU AP) menyebutkan diskresi sebagai keputusan dan/atau tindakan yang ditetapkan dan/atau dilakukan oleh pejabat pemerintahan untuk mengatasi persoalan konkret yang dihadapi dalam penyelenggaraan pemerintahan dalam hal peraturan perundangundangan yang memberinkan pilihan, tidak mengatur, tidak lengkap atau tidak jelas dan/ atau adanya stagnasi pemerintahan. ${ }^{37}$ Tujuan penyelenggaraan pemerintahan; mengisi kekosongan hukum; memberikan kepastian hukum; dan mengatasi stagnasi pemerintahan dalam keadaan tertentu guna kemanfaatan dan kepentingan umum. ${ }^{38}$ Namun, diskresi hanya

33 Ridwan HR, Hukum Administrasi Negara (Jakarta: PT Raja Grafindo Persada, 2017).

34 Adam Setiawan and Nehru Asyikin, "Tanggungjawab Jabatan Dan Tanggungjawab Pribadi Dalam Diskresi Sebagai Instrumen Pelayanan Publik (Public Service)," Mimbar Hukum 32, no. 1 (2020).

35 Ridwan HR, Diskresi Dan Tanggungjawab Pemerintah (Yogyakarta: FH UII Press, 2014).

36 HR, Hukum Administrasi Negara.

37 Lihat Pasal 1 angka 9 UU No. 30 Tahun 2014 Tentang Administrasi Pemerintahan

38 Lihat Pasal 22 ayat (2) UU No. 30 Tahun 2014 tentang Administrasi Pemerintahan. 
dapat dilakukan oleh pejabat pemerintahan yang berwenang, ${ }^{39}$ karena sumber diskresi terletak pada kewewenangan pejabat itu sendiri (inherent aan het bestuur). Hal ini mencakup kebebasan kebijaksanaan (beleidsvrijheid) dan kebebasan penilaian (boerdelingsvrijheid). ${ }^{40}$ Dan ketika diskresi (freies ermessen) tersebut diwujudkan ke dalam instrument yuridis yang tertulis, maka ia menjadi peraturan kebijakan (beleidsregel). ${ }^{41}$ Jadi, ketika peraturan menteri lahir berdasarkan kewenangan yang melekat pada dirinya (jabatan), maka sudah seharusnya dimaknai sebagai peraturan kebijakan (beleidsregel) yang lahir karena adanya freies ermessen.

Di sisi lain, peraturan menteri yang berupa verordnung (peraturan pelaksanaan) justru terikat dengan peraturan perundang-undangan yang lebih tinggi, karena keberadaannya sendiri didasarkan atas perintah peraturan perundangundangan yang lebih tinggi untuk diatur lebih lanjut, sehingga eksistensinya selalu didahului oleh undang-undang (formellgezets) yang menjadi induk dari substansi yang didelegasikan kepada verordnung untuk dilaksanakan. Namun demikian, dalam praktek sebenarnya sangat sulit untuk membedakan antara kedua jenis peraturan menteri tersebut. Menurut Wicipto Setiadi $^{42}$, dalam praktek memang sangat sulit untuk membedakan antara peraturan menteri yang berupa peraturan kebijakan (beleidsregel) dengan peraturan menteri yang berupa peraturan pelaksanaan (verordnung). Menteri dapat membuat peraturan pelaksanaan yang mengikat umum karena perintah delegasi dari peraturan perundang-undangan yang lebih tinggi, dan juga dapat membuat beleidsregel

39 Lihat Pasal 22 ayat (1) UU No. 30 Tahun 2014 tentang Administrasi Pemerintahan.

40 "Penghentian Penyidikan: Tinjauan Hukum Administrasi Dan Hukum Acara Pidana," Safrina, Anne Susilowati, W.M. Herry Ulfah, Maria 29, no. 1 (2017).

41 HR, Hukum Administrasi Negara.

42 Wicipto Setiadi, "Perkuliahan Hukum Perundang-Undangan." karena berdasarkan diskresi, sehingga untuk membedakan antara keduannya harus melihat sumber perintah pendelegasiannya. Akan tetapi dalam kenyataanya, tak jarang beleidsregel juga diberi baju seperti peraturan perundangundangan pada umumnya, sehingga sangat sulit untuk membedakannya

Kedua, kekuatan daya ikat yang berbeda. Bagir Manan mengatakan bahwa beleidsregel merupakan peraturan yang bukan peraturan perundang-undangan tidak langsung mengikat secara umum, tetapi memiliki relevansi hukum. Karena pada dasarnya peraturan ini ditunjukan kepada administrasi negara itu sendiri. ${ }^{43}$ Indroharto menjelaskan bahwa beleidsregel bagi masyarakat menimbulkan keterikatan secara tidak langsung. ${ }^{44}$ Lebih jelas, Maria Farida Indrati ${ }^{45}$ menjelaskan bahwa peraturan menteri dapat mengikat keluar secara umum karena berkaitan dengan fungsinya sebagai unsur eksekutif. Peraturan menteri dapat mengikat keluar apabila diperintahkan peraturan perundang-undangan yang lebih tinggi secara langsung (gebondenbeleids). Sedangkan peraturan menteri tidak mengikat keluar apabila berupa beleidsregel (vrijbelieds). Maka peraturan menteri yang berupa beleidsregel dapat berupa peraturan yang hanya berlaku dalam institusi tersebut.

Kedudukan beleidsregel bukanlah suatu norma hukum (general norm) yang mengikat secara umum, meskipun dalam prakteknya sering terdapat beleidsregel yang juga mencatumkan norma hukum, akan tetapi norma tersebut bukanlah lahir dari beleidsregel tersebut, melainkan turunan dari regeling dalam hierarki jabatan, karena secara hakikat beleidsregel merupakan kebijakan (policy) yang dikeluarkan oleh pejabat untuk mengisi kekosongan hukum yang tidak dijelaskan oleh

43 HR, Hukum Administrasi Negara.

44 HR.

45 Maria Farida Indrati Soeprapto, "Perkuliahan Hukum Perundang-Undangan” (2020). 
peraturan perundang-undangan. Meskipun terdapat regel dan sifatnya berlaku untuk umum, namun perlu dibedakan dengan regeling (mengatur) peraturan perundang-undangan. Dalam Algemen Wet Bestuurrecht (AWB) menjelaskan beleidsregel,

"Onder beleidsregel wordtverstaan: een bij besluit vastgestelde algemene regel, niet zijnde een algemeen verbindend voorschrift, omtrent de afweging van belangen, de vaststelling van feiten of de uitleg van wettelijke voorschriften bij het gebruik van een bevoegdheid van een bestuursorgaan"(policy rules means an order, not being a generally binding regulation which lays down a general rule for weighing interest, determining facts or interpreting statutory regulations in the exercise of a power of an administrative authority). ${ }^{46}$

Sehingga meskipun beleidsregel juga memiliki kekuatan mengikat, namun kekuatan mengikat tersebut merupakan mengikat dalam arti perintah dan tidak mengikat secara umum begitu saja. Dalam konteks administrasi, perintah dapat diartikan sebagai bahasa komunikasi dari atasan kepada bawahan.

Meskipun kedua jenis peraturan tersebut sama-sama dibuat oleh eksekutif. Sejatinya eksekutif tidak memiliki kewenangan untuk membuat menetapkan suatu peraturan yang mengikat (wetgevende bevoegdheid), dikarenakan konsep separation of power. Eksekutif dapat mengeluarkan suatu peraturan (mengikat umum) karena adanya delegated legislation. Konsep delegated legislation dengan diskresi (discretionary) tidaklah sama, meskipun keduanya sama-sama memberikan kewenangan kepada pejabat eksekutif untuk mengeluarkan suatu peraturan. Delegated legislation lebih menitikberatkan kepada kewenangan eksekutif untuk mengeluarkan peraturan perundangundangan dalam rangka melaksanakan perintah

46 Lihat Article 1:3 Aglemen Wet Bestuurecht (AWB) undang-undang (verordnung) yang sejatinya merupakan produk legislasi, yang melahirkan subordinate legislation. Sedangkan diskresi (discretionary) lebih menitikberatkan perannya sebagai pengisi kekosongan hukum. Sehingga jika ditinjau dari segi sifat eksistensinya, diskresi lebih bersifat opsional (choice) karena esensinya ada pada 'pilihan' dan hanya dikeluarkan ketika dibutuhkan (kondisional) dan pejabat dapat memilih untuk melakukan tindakan (do something) atau tidak (do nothing). Sehingga disamping substansi nya berbeda, kekuatan legitimasinya juga tidaklah sama. Maka, daya ikat antara kedua jenis peraturan tersebut juga berbeda.

Ketiga, kedudukan dalam hirarki peraturan perundang-undangan. Berkaitan dengan fungsinya sebagai pengimplementasi kebijakan pusat, secara logis, materi muatan peraturan menteri merupakan penjabaran dari materi muatan peraturan perundang-undangan yang lebih tinggi yang bersumber dari undang-undang (formellgezets) untuk menyelenggaraakan urusan tertentu pemerintahan. Pasal 8 ayat (2) menyebutkan, "peraturan perundangundangan sebagaimana dimaksud pada ayat (1) diakui keberadaannya dan mempunyai kekuatan hukum mengikat sepanjang diperintahkan oleh peraturan perundang-undangan yang lebih tinggi ...". ${ }^{47}$ Mengingat kedudukan struktural kelembagaannya di bawah Presiden secara langsung, maka peraturan perundangundangan yang lebih tinggi berdasarkan hierarki peraturan perundang-undangan yang dapat memerintahkan menteri secara langsung dari perpres ke atas. Sehingga, perintah pembentukan peraturan menteri tersebut dapat dituangkan melalui PP atau pun perpres. Jadi, cukup relevan untuk menempatkan peraturan Menteri (verordnung) di bawah perpres.

Lantas bagaimana jika dibandingkan

47 Lihat Pasal 8 ayat (2) UU No. 12 Tahun 2011 tentang Pembentukan Peraturan Perundang-undangan. 
dengan kedudukan peraturan daerah (provinsi dan kabupaten/kota)? Secara hierarki, perda berada dibawah langsung perpres, berbeda dengan peraturan menteri yang tidak dimasukan ke dalam hierarki peraturan perundangundangan. ${ }^{48}$

Ditinjau dari sumber kewenangan pembentukannya, perda memiliki sumber kewenangan secara atributif langsung dari UUD 1945. Pasal 18 ayat(6) UUD 1945 menyebutkan, "pemerintah daerah berhak menetapkan peraturan daerah dan peraturan-peraturan lain untuk melaksanakan otonomi dan tugas pembantuan". ${ }^{49}$ Sedangkan peraturan menteri lahir berdasarkan perintah peraturan perundangundangan yang lebih tinggi (delegated legislation) baik PP ataupun perpres. Maka dari sumber kewenangan pembentukan, kedudukan perda lebih tinggi daripada peraturan menteri yang hanya dapat dibentuk apabila sebelumnya terdapat perintah dari kewenangan yang sudah ada (atribusi).

Akan tetapi jika ditinjau dari segi keberlakuannya, tentu akan berbeda. Bentuk negara kesatuan memiliki pengaruh yang sangat besar dalam menentukan keberlakuan suatu peraturan. Sehingga sebagai implikasi dari bentuk negara kesatuan, peraturan daerah tidak boleh bertentangan dengan peraturan pusat. Peraturan daerah hanya berlaku pada lingkup otonomnya saja, berbeda dengan peraturan menteri yang merupakan penjabaran dari peraturan pusat yang disektoralkan pada urusan tertentu, sehingga keberlakuan peraturan menteri terikat pada keberlakuan peraturan yang memerintahkannya. Maka peraturan menteri merupakan peraturan pusat sehingga lingkup berlakunya secara nasional dalam arti berlaku di seluruh wilayah Negara Kesatuan Republik

48 Lihat Pasal 7 UU No. 12 Tahun 2011 tentang Pembentukan Peraturan Perundang-undangan.

49 Lihat Pasal 18 ayat (6) Undang Undang Dasar Negara Republik Indonesia 1945.
Indonesia. ${ }^{50}$ Jika ditinjau dari perspektif sistem peraturan perundang-undangan nasional, maka peraturan menteri memiliki hierarki yang lebih tinggi dibandingkan peraturan daerah.

Lalu bagaimana dengan peraturan menteri yang berupa beleidsregel? Mengingat terdapat dua jenis peraturan menteri dalam UU P3, maka sebenarnya perlu dibedakan kedudukan antara keduannya. Mendasar pada pemaparan sebelumnya mengenai daya ikat antara kedua peraturan tersebut. Maka penulis berpendapat bahwa peraturan menteri yang berupa beleidsregel, kedudukannya berbeda dengan peraturan menteri yang berupa verordnung. Karena perbedaan muatan materi, daya ikat dan lingkup keberlakuan, mempengaruhi kedudukannya dalam sistem peraturan perundang-undangan nasional.

Keempat, mekanisme pengujian. Menurut Jimly, pengujian norma hukum peraturan perundang-undangan dilihat dari subyeknya dapat dilakukan oleh hakim (judicial review), oleh legislatif (legislative review), dan oleh eksekutif (executive review). ${ }^{51}$ Dalam konteks "control internal", pemerintah dapat melakukan executive review melalui proses pencabutan atau pembatalan. Akan tetapi, berkaitan dengan pengujian peraturan perundang-undangan, hal ini dianggap kurang tepat karena beririsan dengan kewenagan judicial review baik oleh Mahkamah Konstitusi ataupun Mahkamah Agung. ${ }^{52}$ Pada dasarnya, pengujian peraturan perundang-undangan di bawah undang-undang terhadap undang-undang

50 Aziz, "Pengkajian Hukum Tentang Eksistensi Peraturan Perundang-Undangan Di Luar Hierarki Berdasarkan UU No. 10 Tahun 2004 Tentang Pembentukan Peraturan Perundang-Undangan."

51 Tanto Lailam, "Penataan Kelembagaan Pengujian Norma Hukum Di Indonesia (The Institutional Arrangement of Legal-Norms Review in Indonesia)," Jurnal Konstitusi 15, no. 1 (2018).

52 Taufik H. Simatupang, "Mendudukan Konsep Executive Review Dalam Sistem Hukum Ketatanegaraan Indonesia," Jurnal Penelitian Hukum De Jure 19, no. 2 (2019). 
merupakan kewenangan Mahkamah Agung. Pasal 24A ayat (1) UUD 1945 menyebutkan "Mahkamah Agung berwenang mengadili pada tingkat kasasi, menguji peraturan perundangundangan dibawah undang-undang terhadap undang-undang, dan mempunai wewenang lainnya yang diberikan oleh undang-undang”.

Hal ini kemudian dipertegas dalam Pasal 20 ayat (2) huruf b UU No. 48 Tahun 2009 tentang Kekuasaan Kehakiman jo Pasal 31 ayat (1) UU No. 5 Tahun 2004 tentang Perubahan atas UU No. 14 Tahun 1985 tentang Mahkamah Agung (UU MA) jo Pasal 1 angka 1 Peraturan Mahkamah Agung No. 1 Tahun 2011 tentang HakUji Materil(Perma HUM). Dalam rezimUU $\mathrm{P} 3$, peraturan menteri yang berupa beleidsregel diakui sebagai peraturan perundang-undangan. Sehingga peraturan tersebut dapat diuji oleh MA.

Jika mendasar pada Pasal 1 angka 1 Perma HUM, "Hak uji materil adalah hak Mahkamah Agung untuk menilai materi muatan peraturan perundang-undangan di bawah undang-undang terhadap perauran perundang-undangan tingkat lebih tinggi", maka parameter batu uji (ground review) yang digunakan ialah peraturan perundang-undangan yang lebih tinggi yang berarti pengujiannya secara wetmatigheid. Ini relevan jika diterapkan pada peraturan menteri yang berupa verordnung yang notabene-nya merupakan penjabaran atau perintah dari regulasi yang lebih tinggi. Verordnung dibentuk karena adanya perintah dari peraturan perundang-undangan yang lebih tinggi untuk mengatur lebih lanjut sebagai peraturan pelaksanaan yang bersifat teknis, maka materi muatannya merupakan materi yang didelegasikan dan terikat (gebondenbeleid) pada peraturan perundan-undangan yang lebih tinggi yang bersumber dari undangundang (formellgezets), sehingga substansinya merupakan turunan dari undang-undang.

Berbeda dengan peraturan menteri yang berupa beleidsregel, ia justru lahir karena regulasi yang lebih tinggi tidak mengatur atau belum mengatur secara jelas sebelumnya. Maka potensi ketidakselarasan dengan regulasi yang lebih tinggi tentu menjadi hal yang tak terhindarkan. Pendapat ini semakin diperkuat dengan adanya Pasal 175 angka 2 UU No. 11 Tahun 2020 tentang Cipta Kerja yang merubah ketentuan Pasal 24 angka b UU AP terkait syarat penggunaan diskresi yang tidak bertentangan dengan ketentuan peraturan perundangundangan. Oleh sebab itu, dasar pengujiannya tidak dapat hanya semata-mata didasarkan pada ada tidaknya pertentangan dengan regulasi yang lebih tinggi (wetmatigheid). Poin penting yang juga perlu dipertimbangkan ialah esensi dari beleidsregel itu sendiri, yang lebih menekankan pada efektifitas, efisiensi dan daya guna (doelmatigheid). Hal ini juga berkaitan dengan dasar penggunaan wewenang dalam ranah administrasi, yang mana selain didasarkan pada peraturan perundang-undangan,juga didasarkan pada Asas-asas Umum Pemerintahan Yang Baik (AUPB). ${ }^{53}$ Lebih lanjut, Bagir Manan mengatakan bahwa beleidsregel tidak dapat diuji secara wetmatigheid karena tidak ada dasar peraturan perundang-undangan untuk membuat peraturan tersebut, yang mana justru lahir karena freies ermessen. Sehingga pengujiannya dilakukan secara doelmatigheid, yaitu mendasar pada AUPB. ${ }^{54}$

Konteks hukum administrasi, segala sengketa yang timbul akibat penggunaan wewenang atau tindakan dalam ranah administrasi, tidak serta merta langsung diarahkan ke lingkungan peradilan. Terdapat mekanisme upaya administrasi terlebih dahulu yang mesti ditempuh sebelum dapat mengajukan gugatan ke pengadilan. ${ }^{55}$ Ini juga berlaku terhadap

53 Lihat Pasal 8 ayat (2) UU No. 30 Tahun 2014 tentang Administrasi Pemerintahan.

54 HR, Hukum Administrasi Negara.

55 Lihat Pasal 2 Peraturan Mahkamah Agung No. 6 Tahun 2018 Tentang Pedoman Penyelesaian Sengketa 
kewenangan pengadilan dalam memeriksa ada atau tidaknya unsur penyalahgunaan wewenang, yang mana juga merupakan batasan dalam penggunaan diskresi. Karena penggunaan diskresi sebagai akibat penerapan konsepsi welfare state, menjadikan kewenangan pemerintah menjadi sangat luas, sehingga membuka potensi timbulnya penyalahgunaan wewenang. ${ }^{56}$ Oleh sebab itu, kewenangan tersebut perlu dibatasi dengan unsur larangan penyalahgunaan wewenang. ${ }^{57}$ Maka, pengadilan baru berwenang memeriksa setelah adanya hasil pengawasan aparat pengawas intern pemerintah. ${ }^{58} \mathrm{Hal}$ ini didasarkan pada adagium "de rechter mag niet op de stoel van de administratie gaan zitten" (hakim tidak boleh duduk di atas kursi administrasi). ${ }^{59}$ Philipus M. Hadjon juga menerangkan bahwa kebijakan penguasa tidak termasuk dalam wilayah kompetensi pengadilan kecuali terdapat unsur willekeur dan detournement de puvoir. ${ }^{60}$ Harry Supriyono menjelaskan bahwa penegakan hukum adminsitrasi bukan merupakan wilayah pengadilan (handhaving van het bestuurs-recht), tetapi merupakan bagian dari besturen, sehingga dalam hal ini yang berwenang ialah pejabat administratif. ${ }^{61}$ Sehingga, pejabat administrasi

Administrasi Pemerintahan Setelah Menempuh Upaya Administratif

56 Despan Heryansyah, "Pergeseran Kompetensi

Absolut PTUN Dalam Sistem Hukum Indonesia," Jurnal Hukum Novelty 8, no. 1 (2017).

57 Lihat Pasal 17 UU No. 30 Tahun 2014 tentang

Administrasi Pemerintahan.

58 Lihat Pasal 2 ayat (2) Peraturan Mahkamah

Agung No. 4 Tahun 2015 Tentang Pedoman Beracara

Dalam Penilaian Unsur Penyalahgunaan Wewenang

59 Muhammad Thabrani Mutalib, "Kewenangan Pengadilan Menguji Norma Peraturan Kebijakan (Beleidsregel) Di Indonesia" (Universitas Islam Indonesia, 2017).

60 Philipus M. Hadjon, Perlindungan Bagi Rakyat Di Indonesia: Sebuah Studi Tentang Prinsip-Prinsipnya, Penanganannya Oleh Pengadilan Dalam Lingkungan Peradilan Umum Dan Pembentukan Peradilan Administrasi Negara (Surabaya: PT Bina Ilmu, 1987).

61 Harry Supriyono, "Perkuliahan Hukum Lingkungan" (2020). yang menggunakan diskresi, mendapat jaminan dari judicial review oleh hakim, yangmana terdapat adagium "kebijakan tidak dapat diadili". ${ }^{62}$ Ini menunjukan terdapat batasanbatasan tertentu dimana pengadilan tidak dapat memutus suatu sengketa administratif (fungsi yudikatif). Secara konsepsi, hal ini tentu berpengaruh terhadap pengujian peraturan menteri yang berupa beleidsregel, yang mana sumber kewenangan pembentukannya juga didasarkan pada unsur diskresi.

Di sisi lain, konsep pengujian (judicial review) di MA didasarkan pada ada tidaknya orang yang merasa dirugikan kepentinganya atas keberlakuan suatu peraturan perundangundangan, sehingga jika terdapat orang yang merasa dirugikan, dapat langsung membawanya ke MA. Konsep ini menjadi kurang relevan jika diterapkan pada peraturan menteri yang berupa beleidsregel, karena sejatinya beleidsregel lahir dari tindakan administrasi pemerintahan, sehingga seharusnya juga tunduk pada hukum administrasi. Maka, pengujian beleidsregel juga harus didasarkan pada mekanisme administrasi dengan mengindahkan "de rechter mag niet op de stoel van de administratie gaan zitten" serta mendasar pada penilaian ada atau tidaknya unsur penyalayahgunaan wewenang dan AUPB yang selain merupakan dasar pedoman bagi pejabat administrasi dalam melakukan suatu tindakan/keputusan, juga menjadi salah satu syarat materil pengajuan gugatan dan sebagai dasar pengujian terhadap obyek sengketa ${ }^{63}$ dalam ranah administrasi.

Pertanyaan selanjutnya, apakah MA dapat

62 M. Beni Kurniawan, "Penggunaan Diskresi Dalam Pemberian Status Kewarganegaraan Indonesia Terhadap Archandra Thahar Ditinjau Dari Asas Pemerintahan Yang Baik," Jurnal Penelitian Hukum De Jure 18, no. 2 (2018).

63 Aju Putrijanti, Lapon T. Leonard, and Kartika Widya Utama, "Model Fungsi Pengawasan Oleh Pengadilan Tata Usaha Negara Sebagai Upaya Menuju Tata Kelola Pemerintahan Yang Baik," Mimbar Hukum 29, no. 2 (2017). 
menguji beleidsregel berdasarkan AUPB atau menilai ada atau tidaknya unsur penyalahgunaan wewenang? Secara normatif, baik dalam UU MA maupun Perma No. 1 Tahun 2011 tentang Hak Uji Materil, tidak menyebutkan mengenai uji materil didasarkan AUPB ataupun unsur penyalahgunaan wewenang. Regulasi tersebut hanya mengatur mengenai hak uji materil dan hak uji formil. Sebagaimana tertuang dalam Pasal 31 ayat (2) UU MA menjelaskan, “.. menyatakan tidak sah ... pembentukannya tidak memenuhi ketentuan yang berlaku ...", jo Pasal 6 ayat (2) Perma HUM, “... tersebut sebagai tidak sah atau tidak berlaku untuk umum, ...". ${ }^{64}$ Frasa "tidak sah" dan "pembentukannya tidak memenuhi ketentuan yang berlaku”, mengindikasikan bahwa pengujian peraturan perundang-undangan (HUM) oleh MA di samping menguji secara materil (materieele toetsingsrecht), juga menguji secara formil (formele toetsingsrecht). ${ }^{65}$

Selain itu, UU AP menyebutkan bahwa "pengadilan" yang dimaksud untuk menyelesaikan sengketa administrasi dalam undangundang tersebut adalah PTUN, dan untuk penilaian unsur penyalahgunaan kewenangan, dalam Pasal 21 ayat (6) menyebutkan "putusan Pengadilan Tinggi Tata Usaha Negara sebagaimana dimaksud pada ayat (5) bersifat final dan mengikat"66, maka penanganan perkara tersebut berakhir pada tingkat banding PTTUN. Meskipun sebenarnya belum ada regulasi yang secara eksplisit mengatur Lembaga mana yang berwenang melakukan pengujian beleidsregel, akan tetapi jika kita konsisten meletakan beleidsregel sebagai diskresi dalam bentuk tertulis, maka mekanisme pengujian diskresi

64 Lihat Pasal 6 ayat (2) Peraturan Mahkamah Agung No. 1 Tahun 2011 Tentang Hak Uji Materil

65 Inna Junaenah, "Tafsir Konstitusional Pengujian Peraturan Di Bawah Undang-Undang (Constitutional Interpretation in Judicial Review of Regulation Below the Statute)," Jurnal Konstitusi 13, no. 3 (2016).

66 Lihat Pasal 21 ayat (6) UU No. 30 Tahun 2014 tentang Administrasi Pemerintahan. seharusnya juga dapat diterapkan terhadap beleidsregel sesuai dengan ketentuan hukum administrasi. Hal senada disampaikan dalam penelitian Muhamad Thabrani Mutalib, terkait pengujian beleidsregel oleh MA, ia menjelaskan bahwa pengujian beleidsregel seharusnya dilakukan secara marginale toesting di PTUN. ${ }^{67}$

Dengan demikian, hemat penulis, peraturan menteri yang berupa beleidsregel pun seharusnya diuji layaknya beleidsregel pada umumnya, bukan diuji hanya berdasarkan pada keselarasan dengan peraturan perundangundangan yang lebih tinggi (wetmatigheid) seperti peraturan menteri yang berupa verordnung pada umumnya.

\section{PENUTUP}

Adanya pengakuan terhadap kedua jenis peraturan menteri sebagai bentuk peraturan perundang-undangan dalam UU P3 akan berimplikasi pada penerapannya, sehingga baik peraturan menteri yang berupa verordnung ataupun beleidsregel dapat diberlakukan dan mengikat secara umum. Untuk melihat sumber kewenangan pembentukan peraturan menteri dapat dilihat melalui ada atau tidaknya perintah pembentukan peraturan tersebut. Jika terdapat perintah pembentukan peraturan menteri dari peraturan perundang-undangan yang lebih tinggi, maka peraturan tersebut merupakan peraturan pelaksanaan (verordnung), sedangkan jika tidak terdapat perintah untuk diatur lebih lanjut melalui regulasi tersebut, maka peraturan tersebut dibentuk berdasarkan kewenangannya sebagai menteri yang berarti peraturan menteri berupa beleidsregel. Baik peraturan menteri yang berupa verordnung maupun yang berupa beleidsregel, keduannya memiliki latar belakang, konsep dan karakter yang berbeda, sehingga dari segi substansi, daya ikat, kedudukan hierarki dan mekanisme

67 Mutalib, "Kewenangan Pengadilan Menguji Norma Peraturan Kebijakan (Beleidsregel) Di Indonesia.” 
pengujian tidak dapat disamakan. Oleh sebab itu, peraturan menteri yang berupa beleidsregel tidak dapat diterapkan secara sama seperti peraturan menteri yang berupa peraturan pelaksanaan (verordnung) pada umumnya.

\section{DAFTAR PUSTAKA}

Aglemen Wet Bestuurecht (AWB)

Apendi, Sofyan. "Ketiadaan Peraturan Menteri Dalam Hierarki Peraturan PerundangUndangan Nasional Dan Implikasinya Terhadap Penataan Regulasi Dalam Sistem Hukum Nasional." PALAR (Pakuan Law Review) 07, no. 01

Asshiddiqie, Jimly. Perkembangan Dan Konsolidasi Lembaga Negara Pasca Reformasi. Jakarta: Sekretariat Jenderal dan Kepaniteraan Mahkamah Konstitusi RI, 2006.

Aziz, Noor M. "Pengkajian Hukum Tentang Eksistensi Peraturan Perundang-Undangan Di Luar Hierarki Berdasarkan UU No. 10 Tahun 2004 Tentang Pembentukan Peraturan Perundang-Undangan," 2010.

Hadjon, Philipus M. Perlindungan Bagi Rakyat Di Indonesia: Sebuah Studi Tentang Prinsip-Prinsipnya, Penanganannya Oleh Pengadilan Dalam Lingkungan Peradilan Umum Dan Pembentukan Peradilan Administrasi Negara. Surabaya: PT Bina Ilmu, 1987.

Heryansyah, Despan. "Pergeseran Kompetensi Absolut PTUN Dalam Sistem Hukum Indonesia." Jurnal Hukum Novelty 8, no. 1 (2017).

HR, Ridwan. Diskresi Dan Tanggungjawab Pemerintah. Yogyakarta: FH UII Press, 2014.

-. Hukum Administrasi Negara. Jakarta: PT Raja Grafindo Persada, 2017.

Junaenah, Inna. "Tafsir Konstitusional Pengujian Peraturan Di Bawah Undang-
Undang (Constitutional Interpretation in Judicial Review of Regulation Below the Statute)." Jurnal Konstitusi 13, no. 3 (2016).

Kansil, C.S.T. Sistem Pemerintahan Indonesia. Jakarta: Bumi Aksara, 2005.

Kurniawan, M. Beni. "Penggunaan Diskresi Dalam Pemberian Status Kewarganegaraan Indonesia Terhadap Archandra Thahar Ditinjau Dari Asas Pemerintahan Yang Baik." Jurnal Penelitian Hukum De Jure 18, no. 2 (2018).

Lailam, Tanto. "Penataan Kelembagaan Pengujian Norma Hukum Di Indonesia (The Institutional Arrangement of Legal-Norms Review in Indonesia)." Jurnal Konstitusi 15, no. 1 (2018).

Martini, Rina, Ermaya Suradinata, Murhadam Labolo, and Kusworo Kusworo. "Pemilihan Pejabat Negara Pada Lembaga Negara Penunjang Dalam Sistem Presidensial: Studi Kasus KPU RI Periode 2017-2022." Politika Jurnal Ilmu Politik 10, no. 1 (2019).

Mutalib, Muhammad Thabrani. "Kewenangan Pengadilan Menguji Norma Peraturan Kebijakan (Beleidsregel) Di Indonesia." Universitas Islam Indonesia, 2017.

"Penghentian Penyidikan: Tinjauan Hukum Administrasi Dan Hukum Acara Pidana." Safrina, Anne Susilowati, W.M. Herry Ulfah, Maria 29, no. 1 (2017).

Peraturan Mahkamah Agung No. 1 Tahun 2011 tentang Hak Uji Materil

Peraturan Mahkamah Agung No. 4 Tahun 2015 tentang Pedoman Beracara Dalam Penilaian Unsur Penyalahgunaan Wewenang

Peraturan Mahkamah Agung No. 6 Tahun 2018 tentang Pedoman Penyelesaian Sengketa Administrasi Pemerintahan Setelah Menempuh Upaya Administratif 
Peraturan Menteri Koordinator Bidang Perekonomian No. 2 Tahun 2016 tentang Quick Wins Kementerian Koordinator Bidang Perekonomian

Peraturan Menteri Lingkungan Hidup dan Kehutanan No. P.12/MENLHK/SETJEN/ PLB.3/5/2020 tentang Penyimpanan Limbah Bahan Berbahaya dan Beracun (B3)

Peraturan Pemerintah No. 101 Tahun 2014 tentang Pengelolaan Limbah Bahan Berbahaya dan Beracun (B3)

Peraturan Presiden No. 81 Tahun 2010 tentang Grand Design Reformasi Birokrasi 20102025

Prasetyaningsih, Rahayu. "Menakar Kekuasaan Presiden Dalam Pembentukan Peraturan Perundang-Undangan Menurut UndangUndang Dasar 1945." Padjadjaran Jurnal Ilmu Hukum 4, no. 2 (2017).

Putrijanti, Aju, Lapon T. Leonard, and Kartika Widya Utama. "Model Fungsi Pengawasan Oleh Pengadilan Tata Usaha Negara Sebagai Upaya Menuju Tata Kelola Pemerintahan Yang Baik.” Mimbar Hukum 29, no. 2 (2017).

Rini, Nicken Sarwo. "Penyalahgunaan Kewenangan Administrasi Dalam Undang-Undang Tindak Pidana Korupsi.” Jurnal Penelitian Hukum De Jure 18, no. 2 (2018).

Setiadi, Wicipto. "Perkuliahan Hukum Perundang-Undangan.” 2020.

Setiadi, Wicipto, and Ali Imran Nasution. "Sanksi Administratif Terhadap Kepala Daerah Yang Tidak Melaksanakan Program Strategis Nasional.” Jurnal Penelitian Hukum De Jure 20, no. 4 (2020).

Setiawan, Adam, and Nehru Asyikin. "Tanggungjawab Jabatan Dan Tanggungjawab Pribadi Dalam Diskresi Sebagai Instru- men Pelayanan Publik (Public Service).” Mimbar Hukum 32, no. 1 (2020).

Simatupang, Taufik H. "Mendudukan Konsep Executive Review Dalam Sistem Hukum Ketatanegaraan Indonesia." Jurnal Penelitian Hukum De Jure 19, no. 2 (2019).

Soeprapto, Maria Farida Indrati. "Perkuliahan Hukum Perundang-Undangan.” 2020.

Sukardi, Sukardi, and E. Prajwalita Widiati. "Pendelegasian Pengaturan Oleh Undang-Undang Kepada Peraturan Yang Lebih Rendah Dan Akibat Hukumnya." Yuridika 27, no. 2 (2012).

Supriyono, Harry. "Perkuliahan Hukum Lingkungan.” 2020.

Tesano, Tesano. "Hirarkhisitas Kedudukan Peraturan Menteri Dengan Peraturan Daerah Dalam Sistem Peraturan Perundang-Undangan Ditinjau Dari UndangUndang No. 12 Tahun 2011" 2, no. 2 (2015).

Undang Undang Dasar Negara Republik Indonesia 1945

UU No. 12 Tahun 2011 tentang Pembentukan Peraturan Perundang-undangan

UU No. 30 Tahun 2014 tentang Administrasi Pemerintahan

UU No. 32 Tahun 2009 tentang Pengelolaan Lingkungan Hidup

UU No. 39 Tahun 2008 tentang Kementerian Negara

Zahra, Nindya Chairunnisa. "Kewenangan Pembentukan Peraturan Menteri Sebagai Jenis Peraturan Perundang-Undangan." Universitas Indonesia, 2014. http://lib. ui.ac.id/naskahringkas/2016-10//S58379Nindya Chairunnisa Zahrariyadi. 